\title{
Effects of Agricultural Terraces on the Re- establishment of Bluestem Grasslands
}

\author{
THOMAS B. BRAGG AND LARRY J. STEPHENS
}

\begin{abstract}
The effects of agricultural terraces on the reestablishment of a bluestem grassland were evaluated 5 years after seeding. Terrace intervals (the slopes extending between terraces), terrace channels, terrace ridges, and terrace slopes ( 2 meters downslope from the terrace ridge) in both burned and unburned areas were evaluated. Canopy cover for all seeded native grasses averaged higher on terrace locations than on terrace intervals. Little bluestem (Andropogon scoparius) and Indiangrass (Sorghastrum nutans) were best established in terrace-channels, whereas sideoats grama (Bouteloua curtipendula) and blue grama (B. gracilis) were most abundant on terrace-ridges. Big bluestem (Andopogon gerardii) coverage was greatest on terrace-channels in burned and terrace-slopes in unburned areas. Canopy cover of nonseeded grasses and forbs averaged highest on terrace-ridges and terrace-slopes; forbs were markedly reduced as a consequence of burning but foxtail (Setaria spp.) increased. Total productivity was substantially greater on terrace locations $(6,757$ $\mathrm{kg} / \mathrm{ha}$ ) than on terrace intervals $(3,620 \mathrm{~kg} / \mathrm{ha})$. Burning reduced total biomass the year of the burn with the reduction most pronounced in the terrace-channel where productivity was highest. This study indicates that terraces provide microhabitats which result in species distributions that differ markedly from those expected for native prairies. In addition, terrace conditions appear to slow the process of establishing a continuous stand of native perennial grasses. Thus, it appears to be advisable to remove terraces and redistribute terrace soil prior to reseeding with native grasses.
\end{abstract}

Prior to the arrival of European settlers in the middle and late 1800 's, the vegetation of eastern Nebraska was predominantly bluestem prairie (Andropogon-Panicum-Sorghastrum) (Küchler 1964). Extensive cultivation since that time, however, has substantially reduced the extent of the native prairies and only scattered remnants remain (Nebraska Game and Parks Commission 1972) of which most are either hayed or grazed by cattle (Bose 1977). Recently therc has been an increased interest in maintaining native prairies and in reestablishing native grass stands (U.S. Dep. Agr. 1969; Jenkins 1973) as well as in setting aside native grasslands as research natural areas (Anderson 1946; Kilburn 1970; Christisen 1973; Hulbert 1973; Nyhoff 1975; Riskind and Collins 1975; Riskind and Davis 1975; Darnell 1976). Prairie research areas may be divided into (1) prairie preserves, which are native, unplowed prairies, and (2) reestablished (or restored) grasslands in which previously

Authors are associate professors, Department of Biology and Department of Mathematics and Computer Sciences, University of Nebraska at Omaha, Omaha. Nebraska 68182 .

This study was supported by the Faculty Senate Research Committee, University of Nebraska at Omaha.

The authors express their appreciation to Steven Strong and Darlene Wagner, who assisted in the computer analysis, to James $\mathrm{N}$. Becic, who assisted in portions of the data collection, and Dr. David Sutherland, who assisted with species identification and whose critical reading of this paper added significantly to its quality.

Manuscript received September 5. 1978. cultivated land is reseeded to native prairie species. When managed to approximate pristine conditions, both types of prairie research area play an important role in range management studies by providing base-line information with which the effects of cattle grazing and haying can be compared (Lemon 1975; Schumacher 1975). In addition, research areas provide sites for basic ecological studies of grassland communities.

Studies on various aspects of grassland reestablishment have been reported in Oklahoma, Kansas, Wisconsin, Michigan, Illinois, Utah, and Nebraska (Daniel et al. 1942; Cornelius 1946; Cornelius and Atkins 1946; Cox et al. 1951; Greene and Curtis 1953; Cottam and Wilson 1966; Anderson and Cottam 1970; Bland 1970; Ode 1970; Schulenberg 1970; Hull 1973; Becic and Bragg 1978). Few of these studies, however, refer to burning as a management tool in grassland reestablishment and fewer still deal with the effects of agricultural terracing, a common practice designed to reduce soil erosion and water runoff on sloping, cultivated fields. Cox et al. (1951) noted that terracing in the bluestem-grama prairie region of north-central Oklahoma reduced overall grass production by an average of $31 \%$. Grass biomass averaged $1,350 \mathrm{~kg} / \mathrm{ha}$ on a terraced field in comparison to $4,380 \mathrm{~kg} / \mathrm{ha}$ on an unterraced field. This difference in productivity was attributed to the removal of permeable top-soil from terrace intervals during the establishment of the terraces. Exposed sub-surface soils on the terrace intervals were unable to take in water readily, thus accounting for $13 \%$ more runoff from terraced than from unterraced fields. On terraced fields, Daniel et al. (1942), Cox et al. (1951), and Hull (1973) found that the best grass stand developed in the terrace-ridges or terrace-channel. Productivity on the terrace intervals averaged lower than terrace-ridges or terracechannels; terrace-ridges were either intermediate or lower than other locations.

Daniel et al. (1942) noted that 2 years after seeding, different species of native prairie plants were best established on different terrace locations. Switchgrass (Panicum virgatum) dominated the vegetative cover in the terrace-channel with terrace-ridges and intervals dominated by annual weedy grasses. Canopy cover of blue grama (Bouteloua gracilis) and Indiangrass (Sorghastrum nutans) was greatest on terrace-ridges and intervals, while little bluestem coverage was greatest in terraceridges and intervals, while little bluestem coverage was greatest in terrace-channels. Dropseed (Sporobolus spp.) cover was low in all locations but higher on terrace-ridges than elsewhere. Individual species of native prairie plants that were seeded to previously cultivated but unterraced land were arranged in habitat groupings corresponding to soil-moisture conditions (Cottam and Wilson 1966; Anderson and Cottam 1970). Differences in soil-moisture may also account for the species 
segregation noted on the various terrace-locations.

This study was initiated to evaluate the effects of agricultural terraces on the reestablishment of grasslands in the bluestem prairie region of eastern Nebraska with consideration given to the effects of burning management.

\section{Study Site}

The study was conducted on the 65 .ha Allwine Prairie Preserve located approximately $16 \mathrm{~km}$ northeast of the University of Nebraska at Omaha and situated in the bluestem prairie region of eastern Nebraska (Bragg 1978). The Preserve, managed by the Department of Biology, includes $56 \cdot$ ha of previously cultivated and terraced cropland that was seeded to native prairie grasses in the spring of 1970 . A 53.ha portion, termed the Tallgrass Area, was seeded with big bluestem (Andrpogon gerardii), little bluestem (Andropogon scoparius), sideoats grama (Bouteloua curtipendula), Indiangrass, and Switchgrass at rates of $2.8,1.7,1.1,1.1$, and $0.6 \mathrm{~kg} / \mathrm{ha}$ pure live seed. An additional 3.ha, designated the Midgrass Area, were seeded with little bluestem, sideoats grama, blue grama, and buffalograss (B̈̈̈chloe dactyloides) at $2.2,3.4,2.2$, and $2.2 \mathrm{~kg} / \mathrm{ha}$ pure live seed. A small amount of big bluestem, switchgrass, and Indiangrass was accidentally introduced into the Midgrass Area, apparently in the seeding equipment or in the seed mixture.

Soils of the site are predominantly silt and silty clay loams that developed on loess substrate (Bartlett 1975). The topography is gently rolling with slopes averaging $11 \%$. Terraces are a distinctive feature of the slopes and represent a difference in elevation of approximately 3 meters. Monthly precipitation normally averages $10.0 \mathrm{~cm}$ from April through July, although an avcrage of $7.5 \mathrm{~cm}$ fell during these months in the year of the study.

\section{Methods and Analysis}

The Midgrass Area and portions of the Tallgrass Area were burned in late April 1975. The Midgrass Area had not been previously burned but the Tallgrass Area was burned on May 1, 1974. The portion of the Tallgrass Area not reburned in 1975 was designated as the unburned area for the purpose of this study.

\section{Vegetative Evaluations}

Vegetative evaluations were made during June and July, 1975, in three management areas: the burned Midgrass Area, the burned Tallgrass Area, and the unburned Tallgrass Area. Upper, middle, and lower slopes were separately evaluated within each area. At each of the three slope locations, four strata were evaluated: (1) the terrace interval, situated halfway between terraces, (2) the terrace-channel, the depressed area immediately upslope from the terrace, (3) the terrace-ridge, directly on top of the terrace, and (4) the terraceslope, situated 2 meters downslope from the terrace ridge. The latter three categories combined are termed terraced locations. Vegetative composition of each study stratum was determined within five, systematically located, 2 by 10 meter plots. Within each plot, the canopy cover of all species was evaluated in each of ten, randomly located $1-\mathrm{dm}^{2}(10 \mathrm{~cm}$ by $10 \mathrm{~cm})$ quadrats (canopy coverage techniques from Daubenmire 1959). Coverage categories used were: less than $5 \%$ cover, 5 to $25 \%, 25$ to $50 \%, 50$ to $75 \%, 75$ to $95 \%$, and greater than $95 \%$ cover. Comparisons of species coverage values between study strata were first tested for normality using frequency distribution curves, then evaluated at the 0.05 level of probability using an analysis of variance. Paired differences in species coverage between each study stratum were tested for significance using the Schefee Test (Nie et al. 1975) at the 5\% level.

In addition to species composition, biomass for each study stratum was sampled using three systematically located 0.5 by 1.0 -meter plots situated along each midslope location. All above-ground vegetation in each plot was clipped, separated into grasses and forbs, oven dried at $54^{\circ} \mathrm{C}$ for 48 hours, and weighed.

\section{Measurement of Soil Variables}

Soil-moisture was evaluated at a depth of $23 \mathrm{~cm}$ using a tensio- meter-type soil moisture probe. Five measurements were recorded along each stratum of the middle slope location at each of the three management areas. In addition, soil samples of the upper $23 \mathrm{~cm}$ of the solum were collected. Soil $\mathrm{pH}$, residual nitrate, phosphorous, potassium, and percent organic matter were determined by the Soil Testing Laboratory, Cooperative Extension Service, University of Nebraska-Lincoln. Additional samples were used to determine soil texture.

\section{Results and Discussion}

Five growing-seasons after being seeded with native prairie grass species, big bluestem dominated the burned and unburned Tallgrass Area, averaging $57 \%$ cover, and little bluestem dominated the Midgrass Area, averaging $67 \%$ cover. Coverage values for individual species, however, differed among study strata and burning management areas (Table 1). The methods used for seeding were assumed to have relatively evenly distributed the same proportion of each species of grass seed. Variations in vegetative composition, therefore, were considered to be primarily the result of differential competitive success under the specific conditions existing along each study stratum. Large values obtained for standard deviation of means reflect uneven distribution, which is characteristic of many species evaluated.

\section{Vegetative Composition with Respect to Terrace Location}

Canopy coverage of each seeded grass species was consistently highest on one of the three terrace locations; in no instance was coverage greatest on the terrace interval (Table 1, Fig. 1). In the Tallgrass Area, big bluestem coverage was greatest in terrace-channels and terrace-slopes, little bluestem and Indiangrass were best established in terrace-channels, and sideoats grama was most abundant on terrace-ridges. In the Midgrass Area, little bluestem was most abundant in the terracechannels with sideoats grama and blue grama coverage highest on terrace-ridges. Sideoats and blue grama are common in welldrained prairie sites that frequently are more xeric than those in which big bluestem, little bluestem, and Indiangrass dominate. The occurrence of these species with respect to soil-moisture differences along terraces (Table 2) appears to be consistent with the conditions under which each is expected to occur in native prairies.

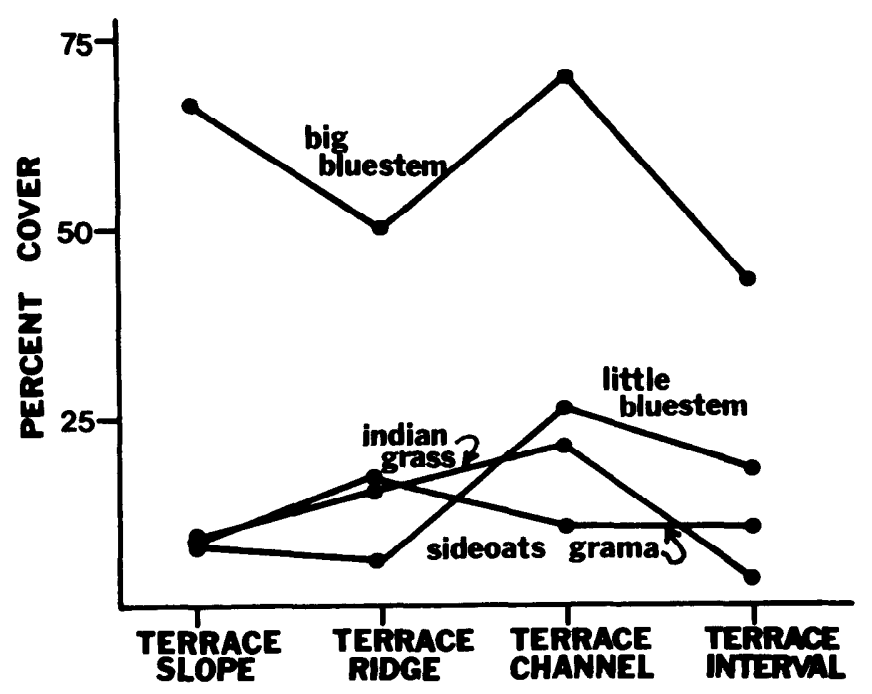

Fig. 1. Canopy coverage differences of seeded perennial grasses on four study strata of the Tallgrass Area. Values represent combined burned and unburned data. 
Table 1. Average percent canopy $\operatorname{cover}^{1}( \pm$ SD) of plant species recorded on burned and unburned study strata. Only species intentionally seeded or species with a frequency greater than $15 \%$ in at least one management area are included.

\begin{tabular}{|c|c|c|c|c|c|c|c|c|c|c|c|c|}
\hline \multirow[b]{2}{*}{ Species } & \multicolumn{4}{|c|}{ Unburned tallgrass area } & \multicolumn{4}{|c|}{ Burned tallgrass area } & \multicolumn{4}{|c|}{ Burned midgrass area } \\
\hline & I & $t-C$ & $t-R$ & $\mathrm{t}-\mathrm{S}$ & I & $t-\mathrm{C}$ & $t-R$ & $\mathrm{t}-\mathrm{S}$ & I & $t-\mathrm{C}$ & $t-r$ & $t-S$ \\
\hline \multicolumn{13}{|l|}{ Seeded perennial grasses } \\
\hline Big bluestem & $39 \pm 41$ & $63 \pm 38$ & $50 \pm 42$ & $67 \pm 38$ & $47 \pm 39$ & $76 \pm 29$ & $\underline{49 \pm 46}$ & $67 \pm 42$ & 0 & 0 & $1 \pm 12 *$ & $13 \pm 32 *$ \\
\hline $\begin{array}{l}\text { (Andropogon gerardii) } \\
\text { Little bluestem }\end{array}$ & $16 \pm 33$ & $23 \pm 37$ & $9 \pm 23$ & $11 \pm 27$ & $20 \pm 34$ & $29 \pm 38$ & $5 \pm 18$ & $5 \pm 17$ & $\underline{53 \pm 36^{*}}$ & $82 \pm 22 *$ & $64 \pm 37^{*}$ & $69 \pm 40^{*}$ \\
\hline $\begin{array}{l}\text { (Andropogon scoparius) } \\
\text { Sideoats grama }\end{array}$ & $10 \pm 21$ & $8 \pm 20$ & $18 \pm 31$ & $12 \pm 27^{*}$ & $12 \pm 25$ & $13 \pm 26$ & $16 \pm 29$ & $5 \pm 20$ & $30 \pm 30^{*}$ & $35 \pm 32 *$ & $55 \pm 34 *$ & $28 \pm 35^{*}$ \\
\hline (Bouteloua curtipendula) & & & & & & & & & & & & \\
\hline $\begin{array}{l}\text { Indiangrass } \\
\quad \text { (Sorghastrum nutans) }\end{array}$ & $6 \pm 20$ & $25 \pm 34$ & $16 \pm 31$ & $10 \pm 24$ & $2 \pm 10$ & $17 \pm 29$ & $17 \pm 34$ & $8+25$ & + & 0 & 0 & 0 \\
\hline Switchgrass & $2 \pm 11$ & $3 \pm 13$ & $2 \pm 12$ & $1 \pm 10$ & $3 \pm 11$ & $6 \pm 18$ & $9 \pm 26$ & $-12 \pm 30$ & 0 & 0 & $1 \pm 9$ & $3 \pm 12$ \\
\hline $\begin{array}{l}\text { (Panicum virgatum) } \\
\text { Blue grama }\end{array}$ & 0 & 0 & 0 & 0 & 0 & 0 & 0 & 0 & $3 \pm 11$ & $4 \pm 12$ & $9 \pm 22$ & $3 \pm 12$ \\
\hline (Bouteloua gracilis) & & & & & & & & & & & & \\
\hline $\begin{array}{l}\text { Buffalo grass } \\
\text { (Buchloe dactyloides) }\end{array}$ & 0 & 0 & 0 & 0 & 0 & 0 & 0 & 0 & + & + & + & + \\
\hline \multicolumn{13}{|l|}{ Nonseeded perennial grass } \\
\hline $\begin{array}{l}\text { Smooth brome } \\
\text { (Bromus inermis) }\end{array}$ & 0 & $1 \pm 6$ & $3 \pm 17$ & $3 \pm 12$ & 0 & + & $5 \pm 19$ & 0 & + & $2 \pm 8$ & $1 \pm 8$ & $1 \pm 4$ \\
\hline \multicolumn{13}{|l|}{ Annual grasses } \\
\hline $\begin{array}{l}\text { Foxtail grass } \\
\quad(\text { Setaria glauca })\end{array}$ & 0 & 0 & $2 \pm 10$ & 0 & 0 & + & $1 \pm 6$ & $1 \pm 6$ & 0 & + & $6 \pm 18$ & $17 \pm 27$ \\
\hline $\begin{array}{l}\text { Foxtail grass } \\
\text { (Setaria viridis) }\end{array}$ & 0 & 0 & $5 \pm 16$ & $1 \pm 6$ & 0 & + & $29 \pm 36^{*}$ & $37 \pm 40^{*}$ & + & $1 \pm 3$ & $3 \pm 11$ & $4 \pm 11$ \\
\hline \multicolumn{13}{|l|}{ Forbs } \\
\hline Wild lettuce & $2 \pm 10^{*}$ & $7 \pm 9 *$ & $20 \pm 26^{*}$ & $12 \pm 20^{*}$ & + & $1 \pm 3$ & $5 \pm 15$ & $11 \pm 24$ & + & $1 \pm 3$ & $2 \pm 8$ & $2 \pm 6$ \\
\hline $\begin{array}{l}\text { (Lactuca canadensis) } \\
\text { Horseweed }\end{array}$ & $9 \pm 17 *$ & $13+15 *$ & $10+19$ & $17 \pm 25$ & & $1+4$ & 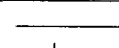 & 0 & + & + & 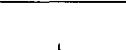 & + \\
\hline $\begin{array}{l}\text { Horseweed } \\
\text { (Conyza canadensis) }\end{array}$ & & $13 \pm 15^{*}$ & $10 \pm 19$ & $17 \pm 25$ & + & $1 \pm 4$ & + & 0 & + & + & + & + \\
\hline Red clover & $16 \pm 30 *$ & $10 \pm 26$ & $2 \pm 10$ & $3 \pm 11$ & + & + & $1 \pm 4$ & + & $2 \pm 12$ & 0 & 0 & 0 \\
\hline $\begin{array}{l}\text { (Trifolium pratense) } \\
\text { Wood sorrel } \\
(\text { Oxalis dellenii) }\end{array}$ & $2 \pm 5^{*}$ & $2 \pm 5$ & $3 \pm 8$ & $3 \pm 6$ & + & + & $4 \pm 11$ & $2 \pm 5$ & + & $2 \pm 5$ & $4 \pm 8$ & $12 \pm 16$ \\
\hline $\begin{array}{l}\text { Yellow sweet clover } \\
\text { (Melilotus officinalis) }\end{array}$ & $12 \pm 29$ & + & 0 & $1 \pm 7$ & 0 & 0 & 0 & 0 & $6 \pm 22$ & $1 \pm 4$ & + & 0 \\
\hline $\begin{array}{l}\text { Lamb's quarters } \\
\text { (Chenopodium album) }\end{array}$ & 0 & 0 & $4 \pm 14$ & $1 \pm 3$ & 0 & $1 \pm 3$ & $6 \pm 15$ & $2 \pm 7$ & 0 & 0 & $1 \pm 4$ & + \\
\hline $\begin{array}{l}\text { Smartweed } \\
\text { (Polygonum pensylvanicum) }\end{array}$ & 0 & 0 & $1 \pm 7$ & + & 0 & + & $3 \pm 9$ & $2 \pm 8$ & + & $2 \pm 6$ & $1 \pm 4$ & $2 \pm 5$ \\
\hline Open soil & $6 \pm 22$ & $2 \pm 6$ & $6 \pm 14$ & $4 \pm 12$ & $245 \pm 37$ & $5 \pm 11$ & $4 \pm 13$ & $2 \pm 6$ & - & $7 \pm 12$ & $3 \pm 8$ & $1 \pm 3$ \\
\hline
\end{tabular}

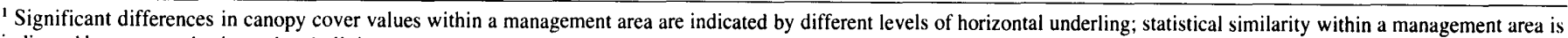

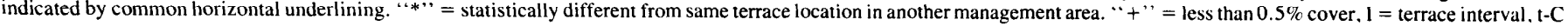
$=$ terrace-channel; $t-R=$ terrace-ridge $;-S=$ terrace slope.

Table 2. Soil characteristics of study strata; management areas combined.

\begin{tabular}{|c|c|c|c|c|c|}
\hline \multirow[b]{3}{*}{ Soil characteristic } & \multirow[b]{3}{*}{ Terrace interval } & \multicolumn{4}{|c|}{ Average Value \pm Standard Deviation of Mean } \\
\hline & & \multicolumn{3}{|c|}{ Terrace-Location } & \multirow[b]{2}{*}{ Number of Samples } \\
\hline & & Channel & Ridge & Slope & \\
\hline $\begin{array}{l}\text { Soil-moisture } \\
\quad \text { (centibars tension) }^{1}\end{array}$ & $27.0 \pm 3.3$ & $17.1 \pm 3.8$ & $25.0 \pm 4.2$ & $22.7 \pm 4.6$ & 15 \\
\hline Organic matter (\%) & $1.7 \pm 0.6$ & $1.4 \pm 0.1$ & $1.5 \pm 0.2$ & $1.8 \pm 0.3$ & 3 \\
\hline Residual nitrate (ppm) & $1.4 \pm 0.1$ & $1.6 \pm 0.2$ & $1.6 \pm 0.2$ & $1.5 \pm 0.3$ & 3 \\
\hline $\mathrm{pH}$ & $6.4 \pm 0.1$ & $7.1 \pm 0.6$ & $7.2 \pm 0.4$ & $7.1 \pm 0.4$ & 3 \\
\hline Phosphorus (ppm) & $4.0 \pm 2.7$ & $3.7 \pm 2.4$ & $4.1 \pm 2.5$ & $3.6 \pm 0.8$ & 3 \\
\hline Potassium (ppm) & $183 \pm 19$ & $190 \pm 14$ & $185 \pm 27$ & $211 \pm 5$ & 3 \\
\hline \multirow[t]{3}{*}{ Soil texture: } & $12.0 \pm 1.0$ & $9.0 \pm 2.6$ & $16.3 \pm 7.1$ & $21.7 \pm 5.5$ & 3 \\
\hline & $56.0 \pm 0.0$ & $60.3 \pm 4.0$ & $52.0 \pm 8.0$ & $48.3 \pm 4.0$ & 3 \\
\hline & $32.0 \pm 1.0$ & $30.1 \pm 1.5$ & $31.7 \pm 1.5$ & $30.0 \pm 2.0$ & 3 \\
\hline
\end{tabular}

\footnotetext{
${ }^{1}$ Values are inversely related to soil-moisture.
} 
Of the four study strata, terrace intervals averaged lowest in soil-moisture, residual nitrate, $\mathrm{pH}$, and potassium (Table 2). These differences, while slight, may account for the poor establishment of seeded grass species on this study stratum. Cox et al. (1951) related lower productivity of terraced fields to reduced permeability which occurred with the exposure of less permeable sub-surface soils during the establishment of terraces. Low soil-moisture values in the terrace-interval, as recorded in the present study, support this conclusion.

When soil-moisture and nutrient availability are adequate, taller species, such as big bluestem, are likely to approach their maximum height and thus more effectively out-compete shorter grasses for light, water, or nutrients. In unburned terracechannels, for example, canopy coverage values of sideoats grama, a mid-height grass, averaged lower than taller grasses. As previously indicated, the maximum coverage of this species occurred on terraced-ridges where soil-moisture and other soil conditions may have restricted the growth of taller grasses. Differences in coverage between big and little bluestem in terrace-channels may also reflect the advantage of height; little bluestem, a shorter grass, is consistently lower in coverage than big bluestem. Differential success among other tall grasses may be related to soil-moisture or nutrient conditions as well, but further studies are needed to substantiate this hypothesis.

Terrace-slopes were found to support the greatest coverage of weedy grasses and forbs with which seeded native grasses had to contend (Fig. 2). Grasses consisted mostly of foxtail; forbs were species common to disturbed areas but uncommon in established native prairies. Field observations indicated that the success of the weedy species in the terrace-slope was partly the result of the poor establishment of native, perennial grasses.

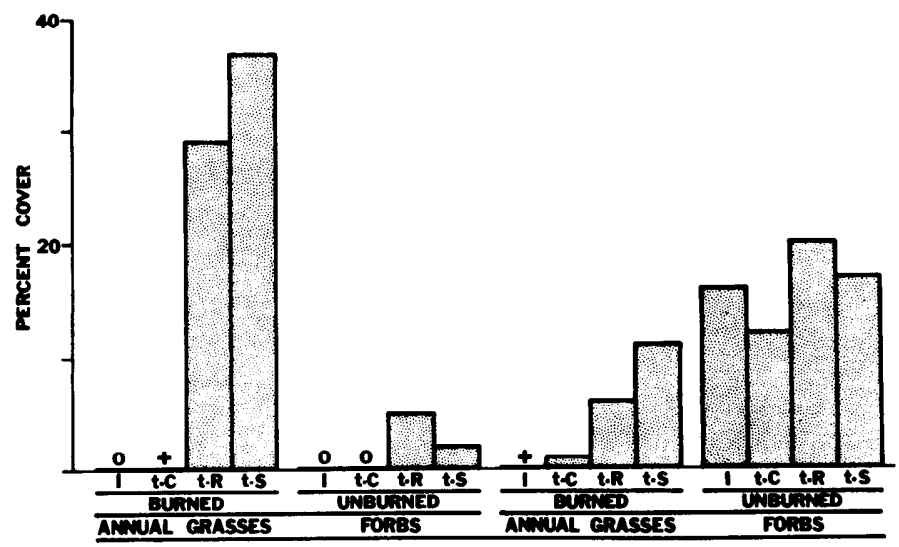

Fig. 2. Weedy grasses and forbs on burned and unburned study strata " $o$ " = absent, "+" = less than $0.5 \%$ cover, $I=$ terrace interval, $t-C=$ terracechaniel, $t-R=$ terrace-ridge; $t-S=$ terrace-slope

This terrace stratum is situated in such a way that seeding may have been difficult thus preventing a good application of grass seed. Poor success as a consequence of competition with weedy species, however, cannot be excluded as a possibility. Where present, seeded grasses grow tall and full, but bare soil is abundant between the individual grass clumps, thus providing an ideal situation for invasion by the weedy species.

\section{Vegetative Composition with Respect to Terrace Location and Burning}

Canopy cover of big bluestem and switchgrass averaged 5\% greater on burned than on unburned strata (Table 1). Differences between burned and unburned strata were greatest on the terrace-channel for big bluestem (13\%) and on the terrace-slope for switchgrass $(11 \%)$. The maximimum coverage of big bluestem occurred in the burned terrace-channel; the highest canopy cover in the unburned area was on terrace-slopes. In contrast, burning decreased Indiangrass coverage by an average of $2 \%$ with the greatest reduction $(8 \%)$ occurring in the terracechannel. The terrace-channel accumulates a greater amount of plant material than other terrace strata thus, when dry, it may support a hotter fire. This is likely to have a greater effect on species that are more sensitive than others to the effects of burning.

Burning significantly reduced the coverage of many forbs but increased that of foxtail (Table 1, Fig. 2). The absence of burning had the opposite effect, substantially reducing foxtail but increasing forb canopy cover. As previously indicated, the area designated as the unburned Tallgrass area was burned in 1974 , the year previous to this study. Substantial differences can be seen between the burned and the unburned areas indicating that the effects of a single burning may be short-lived.

\section{Biomass Production with Respect to Terrace Location and Burning}

In the Tallgrass Area, above-ground vegetative biomass averged $3,260 \mathrm{~kg} / \mathrm{ha}$ on terrace intervals in comparison to 6,757 $\mathrm{kg} / \mathrm{ha}$ for all other terrace strata combined (Fig. 3). This difference is probably due to the soil-moisture and nutrient differences previously discussed. Cox et al. (1951) noted that productivity was lowest on terrace-ridges. His study, however, was conducted on slopes that were more gentle with less distinct terraces than those used for the present study. These variations, in combination with differences in climate and soil, are likely to account for the observed differences in productivity.

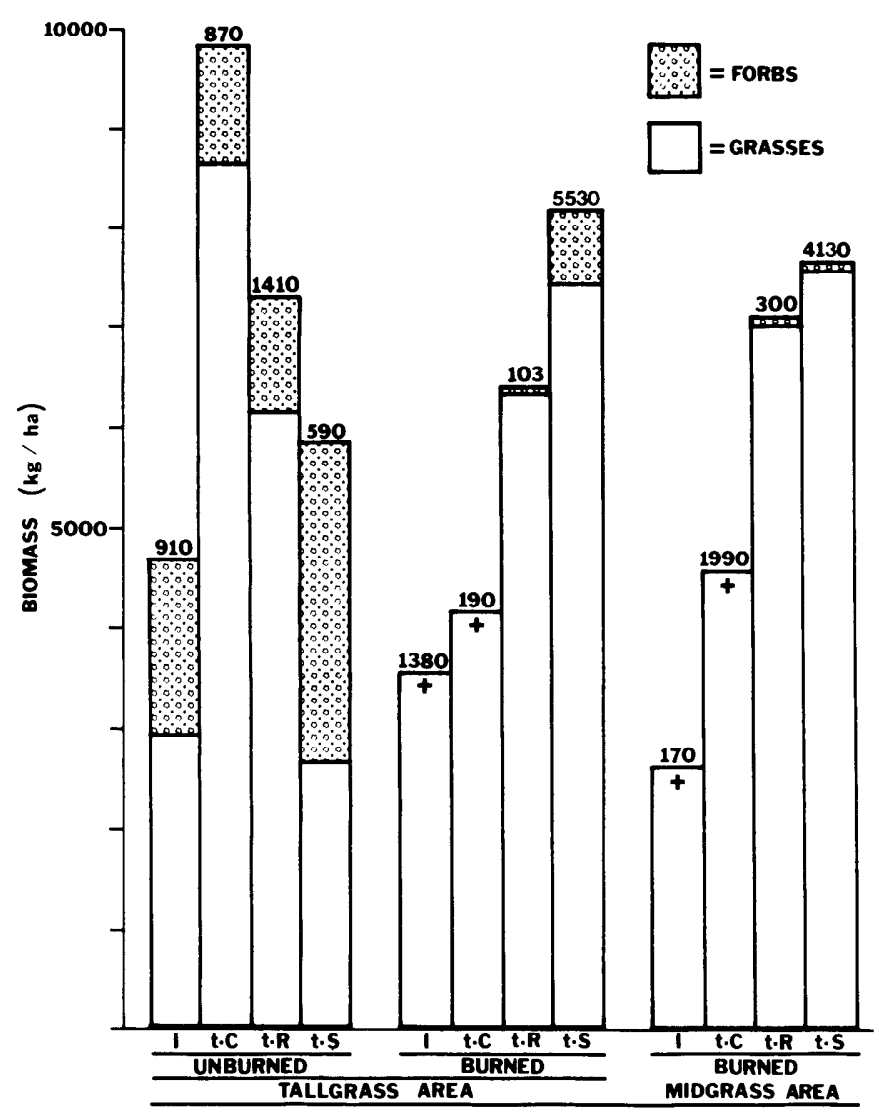

Fig. 3. Grass and forb biomass on burned and unburned study strata. Values above each bar indicate standard deviation of means for total biomass. " +" $=$ forb biomass of less than $50 \mathrm{~kg} / \mathrm{ha}, I=$ terrace interval, $t-C=$ terracechannel, $t-R=$ terrace-ridge, $t-S=$ terrace-slope. 
The principal effect of burning on net above-ground productivity was a substantial reduction in vegetative biomass, with the amount of the reduction occurring in direct proportion to the amount of biomass accumulated prior to the burn. Biomass accumulation was estimated by comparing the data from the burned and from the unburned Tallgrass Areas (Fig. 3). Biomass values were higher in the tcrrace-channel $(9,790$ $\mathrm{kg} / \mathrm{ha})$ than on other study strata $(5,930 \mathrm{~kg} / \mathrm{ha})$. The reduction in biomass as a consequence of burning was greater in terracechannels (a decrease of $5,630 \mathrm{~kg} / \mathrm{ha}$ ) than on other terrace locations (average decrease of $1,000 \mathrm{~kg} / \mathrm{ha}$ ); biomass increased $2,330 \mathrm{~kg} / \mathrm{ha}$ on terracc intervals. These results suggest that when a substantial amount of previous-years' growth accumulates in some terrace location, a fire may be more destructive than in areas where the accumulation is not as great. This situation is likely to be particularly true in reseeded grasslands where the standing dead is primarily grass. The relationship between productivity and terrace location appears to be similar for both the burned Tallgrass and the burned Midgrass Areas. No unburned Midgrass Areas were available for comparison but pre-burn observations indicate that litter accumulation in the Midgrass terrace-channels was substantial.

As previously indicated from canopy coverage data, forb biomass declined sharply as a consequence of burning. Grass biomass (Fig. 2) includes a substantial amount of foxtail (Table 1) thus the success of seeded perennial grasses is less than that indicated by total grass biomass values. Coverage data, however, indicates that burning either favored or did not substantially reduce coverage of the seeded perennial grasses.

\section{Conclusions}

The combined results of this study show that 5 years of vegetative growth and competition on a reestablished grassland resulted in the differential establishment of species with all seeded native grass species favoring some terrace location over terrace intervals. Terracing also provided conditions that supported substantially different amounts of net aboveground productivity. This appears to have affected the establishment of certain, short-statured species and also appears to have altered the effect of burning on species composition. Terraces, thus, provide artificial micro-habitats that alter the distribution of vegetation from that expected for native prairies. In addition, poor conditions on some terrace locations slow the process of establishing a continuous stand of native prairie grasses. These factors, in conjunction with others, such as the alteration of natural water runoff patterns as well as the potential for severe erosion between time of seeding and time of vegetative establishment, must be considered in relation to the desired use of the future grassland. The results of this study, however, indicate that whenever possible it is advisable to remove terraces and redistribute terrace soil prior to seeding cultivated land to native grasses.

\section{Literature Cited}

Anderson, M. Rebecca, and Grant Cottam. 1970. Vegetational change on the Greene Prairie in relation to soil characteristics. Knox Coll. Biol. Field Sta. Spec. Pub. 3:42-45. In: Peter Schramm, ed., Proc. of a Symp. on Prairie and Prairie Restoration; Knox College, Galesburg, Ill.

Anderson, W.A. 1946. Development of prairie at Iowa Lakeside Laboratory. Amer. Midland Natur. 36:431-455.

Bartlett, Paul A. 1975. Soil Survey of Douglas and Sarpy Counties, Nebraska. U.S. Dep. Agr., Soil Conserv. Ser. Pub. in cooperation with Univ. of Nebraska Conserv. and Surv. Div. 82 p.

Becic, James N., and Thomas B. Bragg. 1978. Grassland reestablishment in eastern Nebraska using burning and mowing management. p. 120-124 In: D.C. Glenn-Lewin and R.Q. Landers, eds., Proc. Fifth Midwest Prairie Conf.: Iowa State Univ., Ames, Ia. land, Marilyn K. 1970. Prairie establishment at the Michigan Botanical Gardens. Knox Coll. Biol. Field Sta. Spec. Pub. 3:46-47. In: Peter Schramm. ed., Proc. of a Symp. on Prairie and Prairie Restoration, Knox Coll., Galesburg, Ill.

Bose, Dan R., Coordinator. 1977. Rangeland Resources of Nebraska. Soc. Range Manage., Old West Regional Range Program. Denver, Colo. 121 p.

Bragg, Thomas B. 1978. Allwine Prairie Preserve: a reestablished bluestem grassland research area. p. 114-119. In: D.C. Glenn-Lewin and R.Q. Landers, eds., Proc. Fifth Midwest Prairie Conf.; Iowa State Univ. Ames,

Christisen, Donald M. 1973. Prairie preservation in Missouri p. 42-46. In: Lloyd Hulbert, ed., Third Midwest Prairie Conf. Proc.; Div. of Biol., Kansas State Univ., Manhattan, Kans.

Cornelius, Donald R. 1946. Establishment of some true prairie species following reseeding. Ecology 27: 1-12.

Cornelius, Donald R., and M. Donald Atkins. 1946. Grass establishment and development studies in Morton County, Kansas. Ecology 27: 342-353.

Cottam, Grant, and H.C. Wilson. 1966. Community dynamics on an artificial prairie. Ecology 47: 88-96.

Cox, Maurice B., Harley A. Daniel, and Harry M. Elwell. 1951. Terraces on grassland: A study of terraced and unterraced areas on eroded shallow soil, before and after revegetation with native grasses. Oklahoma Agr. Exp. Sta. Bull. B-373: 5-13.

Daniel, Harley A., Harry M. Elwell, and H.F. Murphy. 1942. Conservation and better land use for Oklahoma. Oklahoma Agr. Exp. Sta. Bull. B-257. 53 p.

Darnell, Rezneat M. 1976. Natural area preservation: The US/IBP Conservation of Ecosystem Program. Bioscience 26: 105-108.

Daubenmire, R. 1959. A canopy-coverage method of vegetational analysis. Northwest Sci. 33(1):43-64.

Greene, H.C., and J.T. Curtis. 1953. The re-establishment of an artificial prairie in the University of Wisconsin Arboretum. Wild Flower 29: 77-88.

Hulbert, Lloyd C. 1973. Managment of Konza Prairie to approximate prewhite-man fire influences. p. 14-17. In: Lloyd C. Hulbert, ed., Third Midwest Prairie Conf. Proc.; Div. of Biol., Kansas State Univ., Manhattan,

Hull, A.C. Jr. 1973. Duration of seeded stands on terraced mountain lands, Davis County, Utah. J. Range Manage. 26: 133-136.

Jenkins, Robert. 1973. Ecosystem restoration. p. 23-27. In: Lloyd C. Hulbert, ed, Third Midwest Prairie Conf. Proc., Div. of Biol., Kansas State Univ., Manhattan, Kans.

Kilburn, Paul D. 1970. Hill Prairie restoration. Knox Coll. Biol. Field Sta. Spec. Pub. 3:50-51. In: Peter Schramm, ed., Proc. of a Symp. on Prairie and Prairie Restoration; Knox College, Galesburg, Ill.

Küchler, A.W. 1964. Potential natural vegetation of the conterminous United States. Amer. Geogr. Soc. Spec. Pub. 36. 116 p.

Lemon, Paul C. 1975. Prairie ecosystems are essential for environmental monitoring. p. 343-348. In: Mohan K. Wali, ed., Prairie: A Multiple View; Univ. of North Dakota, Grand Forks, N.D.

Nebraska Game and Parks Commission. 1972. The Nebraska Fish and Wildlife Plan, Vol. I, Nebraska Wildlife Resource Inventory. Nebraska Game and Parks Comm., Lincolns, Neb. 242 p.

Nie, Norman H., C. Hadlai Hull, Jean G. Jenkins, Karin Steinbrenner, and Dale H. Bent. 1975. Statistical Package for the Social Sciences, 2nd Ed. McGraw-Hill, San Francisco. 675 p.

Nyhoff, Joseph J. 1975. The use of Goose Lake Prairie State Park. p. 383387. In: Mohan K. Wali, ed., Prairie: A Multiple View; Univ. of North Dakota, Grand Forks, N.D.

Ode, Arthur H. 1970. Some aspects of establishing prairie species by direct seeding. Knox College Field Sta. Spec. Pub. 3:52-60. In: Peter Schramm, ed., Proc. of a Symp. on Prairie and Prairie Restoration; Knox College Galesburg, IIl.

Riskind, David H., and O. Brown Collins. 1975. The Blackland Prairie of Texas: Conservation of representative climax remnants. p. 361-367 In: Mohan K. Wali, ed., Prairie: A Multiple View; Univ. of North Dakota, Grand Forks, N.D.

Riskind, David H., and Arnold G. Davis. 1975. Prairie management and restoration in the State Parks of Texas. p. 369-? . In: Mohan K. Wali, ed., Prairie: A Multiple View; Univ. of North Dakota, Grand Forks, N.D.

Schulenberg, Ray. 1970. Summary of Morton Arboretum Prairie Restoration Work, 1963 to 1968. Knox College Biol. Field Sta. Pub. 3:45-56. In: Peter Schramm, ed., Proc. of a Symp. on Prairie and Prairie Restoration; Knox College; Galesburg, III.

Schumacher, C.M. 1975. Rangeland-A proper prairie use. p. 419-442. In: Mohan K. Wali, ed., Prairie: A Multiple View; Univ. of North Dakota. Grand Forks, N.D.

U.S. Department of Agriculture. 1969. Nebraska Conservation Needs Inventory. Rep. of the Nebraska State Soil and Water Conserv. Needs Inventory Comm., Washington, D.C. 259 p. 